\title{
Effect of a microwave drying process as a pretreatment for preservative impregnation on sugi round timbers
}

\author{
Jinji PIAO*1, Noboru FuJIMOTO*2*, Kanehiro OOHASHI ${ }^{* 3}$, \\ Mitsuru Tanikawa*4, Masashi Kitada*4, Hozumi Sonobe*4, \\ YO UEDA* 4
}

スギ円柱材に対するマイクロ波加熱乾燥の加圧注入前処理としての効果

朴 今姫 ${ }^{* 1}$, 藤本 登留 ${ }^{*}$, , 大橋 兼廣 ${ }^{* 3}$, 谷川 充 ${ }^{* 4}$ 北田 正司 ${ }^{* 4}$, 園部 宝積*4, 上田 洋*4

マイクロ波加熱乾燥を加圧注入前処理としてスギ心持ち円柱材に適用した効果について検 討した。背割り無し，一本および四本の背割りを入れたスギ心持ち円柱材について，マイタ 口波加熱乾燥および蒸気乾燥を行った。それぞれの乾燥後に横断面内含水率分布を材長方向 位置別に調べたところ, 蒸気乾燥では低下しない内層部の含水率が, マイクロ波加熱乾燥で は大きく低下する傾向が明らかになった。また，蒸気乾燥で多数発生した背割りなし材での 表面割れについても，マイクロ波加熱乾燥においては過乾燥でないかぎりほとんど見られな かった。加圧注入試験の結果, マイクロ波加熱処理円柱材は蒸気乾燥円柱材に比べ浸潤面積 が大きな值を示した。一本背割り材と四本背割り材の間に浸潤面積の明確な違いは見られな かった。

A microwave drying (MD) process was applied for sugi round timbers, as a pretreatment for effective impregnation of wood preservatives.

In most MD process, the center layers of round timbers were maintained at higher temperature than the outer layers. As a consequence, the moisture content (MC) of the inner layer dropped down significantly in comparison with that of the outer layer in the round timbers. At the same

\footnotetext{
* 1 九州大学大学院生物資源環境科学府 Laboratory of Wood Technology, Department of Forest and Forest Products Sciences, Graduate School of Bioresource and Bioenvironmental Sciences, Kyushu University

*2 九州大学大学院農学研究院 Laboratory of Wood Technology, Department of Forest and Forest Products Sciences, Faculty of Agriculture Graduate Schools of Kyushu University

*3 株式会社西細业製作所 Asia Seisakusyo

*4 株式会社ザイエンス Xyence Corporation

※Corresponding author (E-mail : fujipon@agr.kyushu-u.ac.jp)
} 
time, the MD-dried timbers could reach a low level of MC more quickly than the kiln-dried timbers. In addition, the timbers dried by MD showed less surface checks than those dried by kiln drying (KD), even if without kerf. However, internal checks occurred frequently in most of the MD-dried timbers, which was related to the low final MC.

The timbers dried by MD, but not by KD, showed an elevated ratio of impregnated area of the preservative in the cross-section. Among timbers with 0,1 or 4 kerfs, there was no significant difference in the penetration area of the preservative.

Keywords : sugi round timber, moisture content, microwave heating, preservative impregnation

\section{INTRODUCTION}

Domestic timbers such as sugi (Cryptomeria japonica D.Don), karamatsu (Larix leptolepis Gord.) and hinoki (Chamaecyparis obtusa Endl.) are responsible for a key role in the production of outdoor play equipments and in engineering applications, and have applications in a broad array of other fields. For most of these applications, wood materials should be treated with preservatives to prevent decay and termite attacks.

It is important to control moisture content (MC) of wood for resulting in the effective permeability of wood preservatives ${ }^{1-4)}$. Practically, it is difficult to dry up wood to an ideal MC for the short drying term without defects.

Novel drying processes are necessary to achieve suitable MC for improving the permeability of wood preservatives. Several drying methods such as microwave drying (MD), kiln drying (KD) and air drying have been comparatively studied as pretreatments for the impregnation processes ${ }^{5}$. Among these, MD has been proven to be potentially more effective for improving preservative permeability in sugi round timbers.

We further studied the effect of MD on sugi round timbers to expand the practical application conditions of MD as a pretreatment for preservative impregnation processes. With KD as a comparative process, the temperature distributions, MC diversifications and distributions, and qualities of the dried timbers, as well as the ratio of penetration area after MD were measured to optimize the preservative impregnation conditions.

\section{MATERIALS AND METHODS}

\subsection{Materials}

Drying tests were carried out on sugi boxed heart round timbers $(12 \mathrm{~cm}$ and $9 \mathrm{~cm}$ in diameter, $3 \mathrm{~m}$ in length) with 0,1 and 4 kerfs. Two cm-thick discs were sampled at points $30 \mathrm{~cm}$ along the length from both ends (Fig.1) followed by dividing into 15 pieces to determine initial $\mathrm{MC}$ as shown in Fig.2. In order to determine the MC distribution in the timbers, the

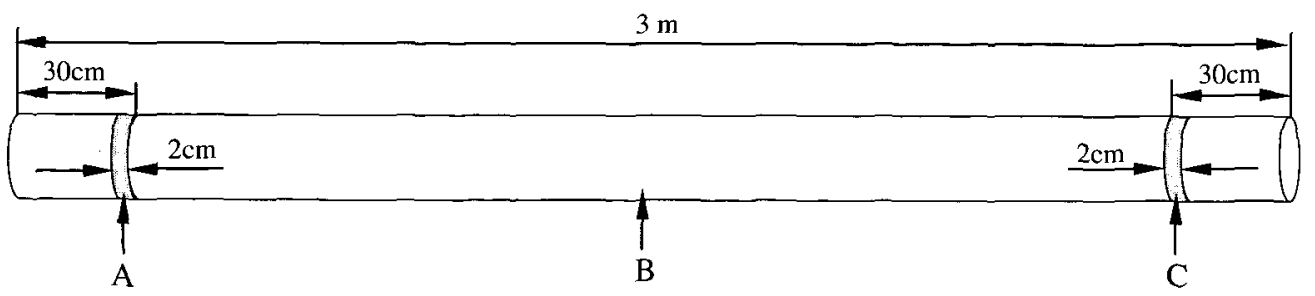

Fig.1 Sampling of discs for determining $\mathrm{MC}$ and a timber sample for drying test from a green round timber

Note : $\mathrm{A}$ and $\mathrm{C}$-for determining initial MC, B-for drying test

図 1 初期含水率分布測定用円盤と乾燥試験用丸太の採取法

注：A，C-初期 MC 測定用，B-乾燥試験用 


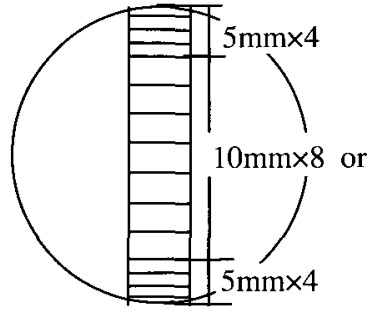

Without kerf

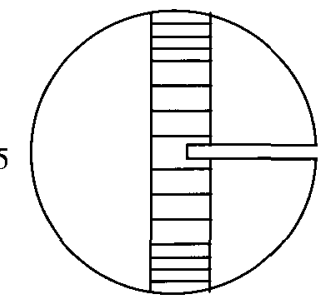

With a kerf

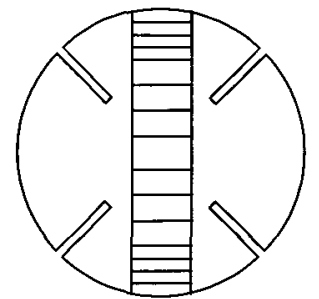

With 4 kerfs

Fig.2 Splitting of discs for determining MC distribution

図 2 含水率分布測定用円盤の分割法

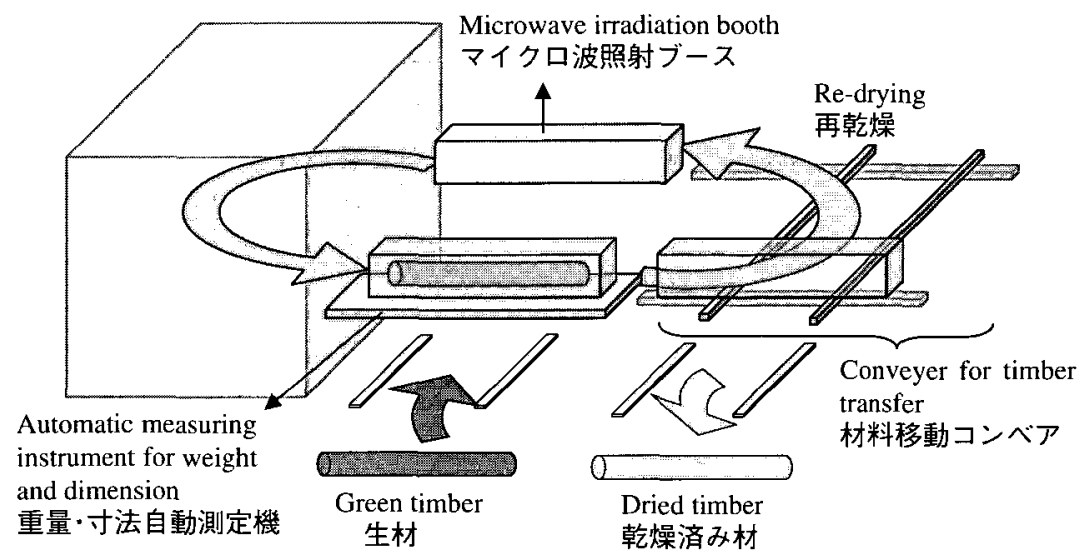

Fig.3 Flow chart of MD system

Microwave irradiation unit : $2450 \mathrm{MHz}$, maximum power output 1.5 kw (change ability) $\times 20$

図 3 マイクロ波乾燥装置の処理工程図

マイクロ波照射ユニット：2450MHz, 最大出力 $1.5 \mathrm{kw}$ (可変) $\times 20$ 基

pieces were weighed before and after oven-drying at $105^{\circ} \mathrm{C}$ for 24 hours. The remainders of the $2.4 \mathrm{~m}$ long round timbers were used for drying tests.

\subsection{Drying tests}

MD was conducted with a $\log$ drying facility ${ }^{6}$ (Asia Seisakusyo) equipped with an automatic measuring instrument and a recycle process facility as indicated in Fig.3. First, green-timbers were transferred into the weight/dimension automatic measuring instrument. Based on measured weight and dimension, the presumptive MCs were predicted according to Expression 1 as shown below. Second, the weighed timbers were automatically conveyed into the microwave irradiation booth. Microwaves were irradiated intermittently (30 seconds irradiation, 12 seconds rest) until the maximum temperature of round timbers reached the target point $\left(140^{\circ} \mathrm{C}\right)$.
Third, the heated timbers were then left in the ventilation booth over 30 minutes without further heating. These processes were repeated until the target MC was achieved and the dried timbers were taken out.

$\mathrm{KD}$ (DBT- $80^{\circ} \mathrm{C}, \mathrm{WBT}-70^{\circ} \mathrm{C}$ and duration-2 days) was conducted as a control process for comparison with MD.

Table 1 shows numbers of $12 \mathrm{~cm}$ and $9 \mathrm{~cm}$-diam. timbers for each drying condition of $\mathrm{MD}$ and $\mathrm{KD}$ tests. After each drying process, a timber $(2.4 \mathrm{~m})$ was divided equally into ten bolts in order to prepare 9 discs $(2 \mathrm{~cm})$ among them. The discs were used for determining $\mathrm{MC}$.

\subsection{Measurement of timber temperature}

For measuring the temperature, the round timbers were drilled 3 holes in each position of 30,80 and $120 \mathrm{~cm}$ from one end. Three holes were drilled into 
Table 1 Number of sugi round timbers on each drying condition 表 1 スギ円柱材の処理条件と処理本数

\begin{tabular}{|c|c|c|c|c|c|c|c|c|c|c|}
\hline & \multicolumn{5}{|c|}{$\begin{array}{l}\text { Microwave drying(MD) } \\
\text { マイクロ波乾燥 }\end{array}$} & \multicolumn{4}{|c|}{$\begin{array}{l}\text { Kiln drying (KD) } \\
\text { 蒸気乾燥 }\end{array}$} & \multirow[t]{2}{*}{$\begin{array}{l}\text { Total number } \\
\text { 合計本数 }\end{array}$} \\
\hline $\begin{array}{l}\text { Target MC } \\
\text { 目標含水率 }\end{array}$ & $40 \%$ & & $30 \%$ & & $20 \%$ & $40 \%$ & & $30 \%$ & & \\
\hline $\begin{array}{c}\text { Number of kerf per timber } \\
\text { 背割りの数 }\end{array}$ & 0 & 0 & 1 & 4 & 0 & 0 & 0 & 1 & 4 & \\
\hline $\begin{array}{l}\text { Sample number of drying test } \\
\text { 乾燥処理本数 }\end{array}$ & 4 & 4 & 4 & 4 & 4 & 4 & 4 & 4 & 4 & 36 \\
\hline $\begin{array}{c}\text { Sample number of preservative } \\
\text { impregnation test } \\
\text { 薬剂注入処理本数 }\end{array}$ & 3 & 3 & 3 & 3 & 3 & 3 & 3 & 3 & 3 & 27 \\
\hline
\end{tabular}

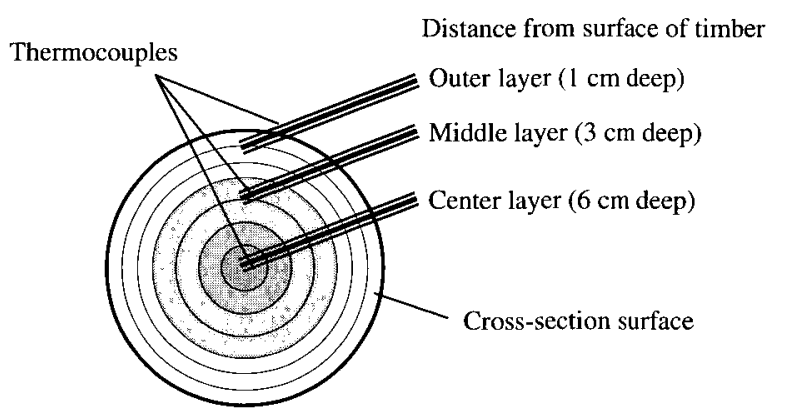

Fig.4 Positions for measuring temperature of tested timber

図 4 材内温度測定位置

the outer layer $(1 \mathrm{~cm}$-deep), the middle layer $(3 \mathrm{~cm}$ deep), and the center layer ( $6 \mathrm{~cm}$-deep) of the timbers using a 3 mm-diam.drill, respectively (Fig.4). Then, a thermocouple (alumel-chromel) covered with an aluminum pipe of $3 \mathrm{~mm}$-diam.was inserted into each hole, and a silicon caulking agent was used to seal them in. The lines of the thermocouples were wrapped with aluminum foil so that microwaves would not affect the thermocouples. A personal computer equipped with the NR-1500 data collection system (Keyence Corporation) was used to record temperatures. The temperatures were recorded every second during the process of heating with microwave irradiation as well as during the cooling process (about 10 minutes) that followed the end of the heating.

\subsection{Measurements of MC and checks of the timbers after drying}

After drying, $2 \mathrm{~cm}$-thick discs were sampled at points $30 \mathrm{~cm}$ along the length from both ends for measuring MCs distribution in cross-section of timbers, according to the methods mentioned above for initial MC determination.

The presumptive $\mathrm{MC}\left(M C_{1}\right)$ and the actual $\mathrm{MC}$ $\left(M C_{2}\right)$ were calculated using Expression 1, 2 as shown below. The MC predicted from the assumptive oven-dry density $\left(D\right.$, assumed $\left.0.35 \mathrm{~g} / \mathrm{cm}^{3}\right)$ was designated as $M C_{1}$, and that calculated from $\mathrm{MC}$ $\left(M C_{0}\right)$ by the oven-dry method after drying was designated as $M C_{2}$.

$$
\begin{aligned}
& M C_{1}(\%)=\frac{G-V \cdot D}{V \cdot D} \times 100 \\
& M C_{2}(\%)=\frac{G-\frac{G_{0}}{1+M C_{0} / 100}}{\frac{G_{0}}{1+M C_{0} / 100}} \times 100 \\
& V: \text { volume of a round timber }\left(\mathrm{cm}^{3}\right) \\
& G: \text { timber mass during drying }(\mathrm{g}) \\
& G_{0}: \text { timber mass after drying process }(\mathrm{g})
\end{aligned}
$$

The surface and internal checks were examined after drying. Surface checks were expressed as the total sum of surface checking area of the tested timber. Internal checks were estimated from the checked area visualized with an image analyzer.

\subsection{Determination of preservative penetration}

The AAC wood preservative (Pentacure New BM, active ingredient: didecyldimethylammonium chloride) was used for impregnation tests with an impregnation cylinder provided by Xyence Corporation under operation conditions consistent with those required by JIS A 9002 . The dose of the preservative for each wood sample was calculated using Expres- 
sion 3 as shown below.

$$
I=\frac{M_{2}-M_{1}}{V_{1}}
$$

$I$ : amount of impregnated preservative $(\mathrm{kg} /$ $\mathrm{m}^{3}$ )

$M_{1}$ : mass of timber before impregnation $(\mathrm{kg})$

$M_{2}$ : mass of timber after impregnation $(\mathrm{kg})$

$V_{1}$ : volume of timber $\left(\mathrm{m}^{3}\right)$

To measure penetration area in the cross-section, each of the impregnated timbers $(1.8 \mathrm{~m})$ was divided equally into six bolts in order to prepare five discs ( 2 $\mathrm{cm}$ ) among them. The $2 \mathrm{~cm}$-discs were tested according to the color reaction method using $18 \%(\mathrm{w} /$ $\mathrm{v})$ acetic acid in water and $0.2 \%(\mathrm{w} / \mathrm{v})$ bromophenol blue in acetone standardized in JAS for sawn timbers. The penetration area was calculated with an image analysis software (Win ROOF Version 3.0, Mitani Corporation).

\section{RESULTS AND DISCUSSION}

\subsection{Temperature distribution of timbers dur-} ing drying

Temperature distribution of the timbers during MD is one of the important parameters for evaluating the efficiency of the drying. We first measured the changes of internal temperatures of the timbers irradiated by microwaves during the $1 \mathrm{st}, 3 \mathrm{rd}$ and $7 \mathrm{th}$ cycles. As shown in Fig.5, in the first cycle of heating, the outer layer was heated as quickly as the center
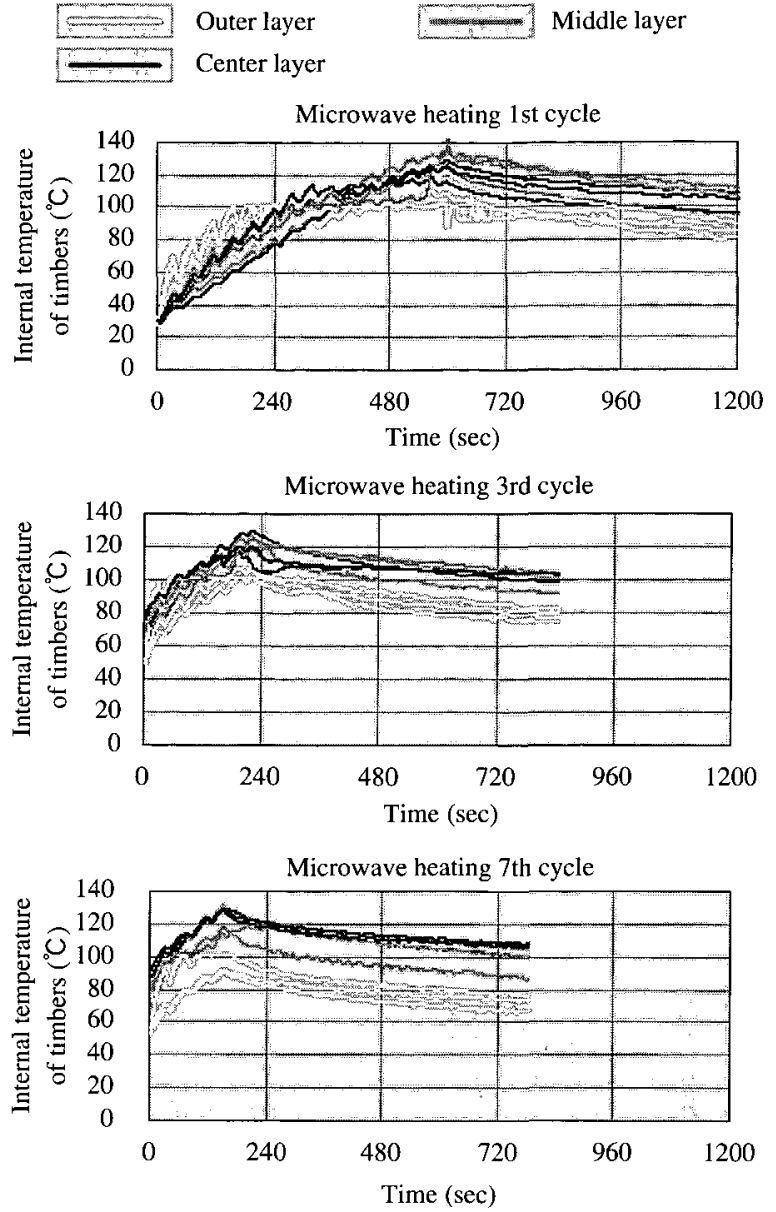

Fig.5 Temperature change of timbers during and after microwave heating

図 5 マイクロ波加熱時および放置時の材内温度変 化

and middle layer. All the temperatures of tested timbers rose to $100^{\circ} \mathrm{C}$ after 6 minutes heating, and the middle layer reached as high as $130^{\circ} \mathrm{C}$. The reason
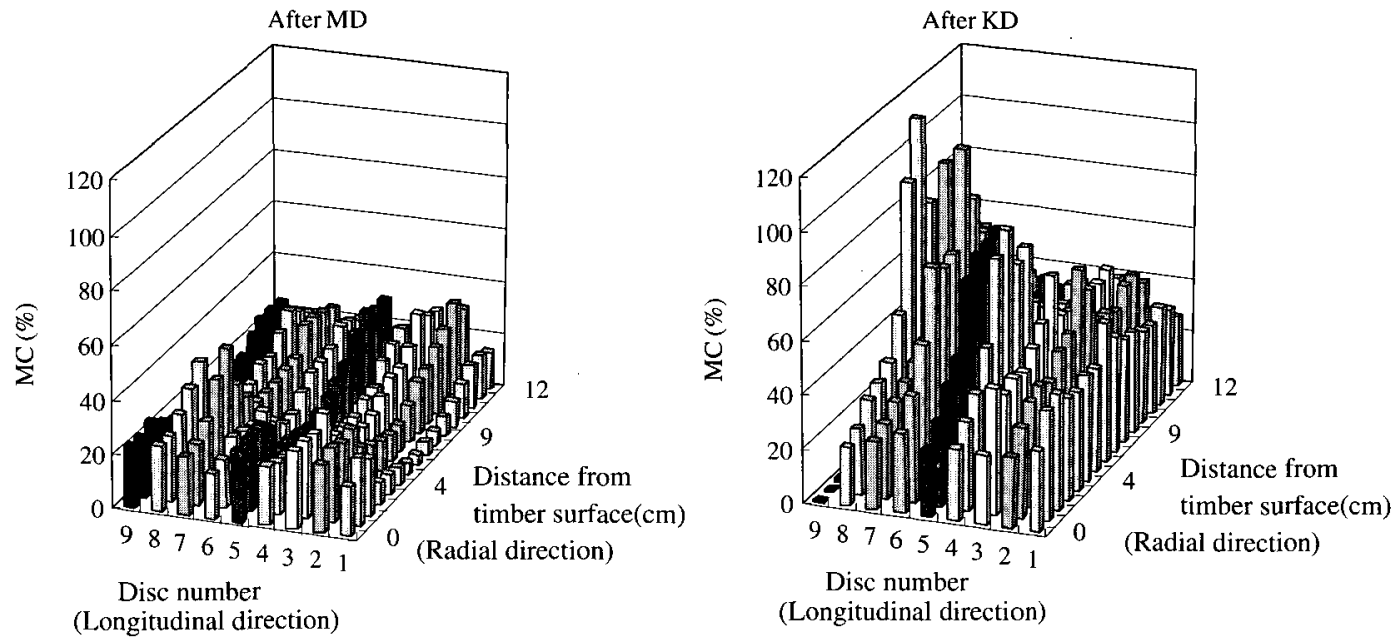

Fig.6 MC distributions in radial and longitudinal directions of tested log

図 6 乾燥後の直径方向と材長方向含水率分布 
of the quick elevation of the center and middle layers of timber temperature up to over $100^{\circ} \mathrm{C}$ might be a higher pressure at the center and middle layers. After the microwave heating, the temperature of the outer layer fell down more quickly than that of the center layer.

Before beginning of the 3rd and the 7th cycles, the temperature of the outer layer dropped to $50-60^{\circ} \mathrm{C}$ and that of the center layer dropped to $70-90^{\circ} \mathrm{C}$. Both center and outer layer temperatures rose equally at the beginning of each cycle. Microwave heating time was shortened along with increasing of the cycles. For instance, 200 and 150 seconds were taken at the $3 \mathrm{rd}$ and the 7 th cycle, respectively. Immediately after heating 3 rd and 7 th, the center temperature showed higher than that of the outer layer, and the center temperature was maintained at $100^{\circ} \mathrm{C}$ or more for about 10 minutes.

\subsection{MC distribution}

Fig. 6 shows MC distribution in timbers dried under each drying process. In MD, the timber MC went down to about $30 \%$, with a lower $\mathrm{MC}$ in the inner layer than in the outer layer. During most of the tested periods, the temperature of the center layer was the highest among all the measured positions in the cross section. The inner layer MC dropped significantly during MD, but appeared comparatively high in KD process. These findings suggest that MD will be a useful drying method to make uniform permeability of the preservative at the inner layer and outer layer.

\subsection{Drying curve}

Fig.7 shows the changes of MC in sugi round timber without kerf. When the presumptive $\mathrm{MC}\left(M C_{1}\right)$ was equal to the actual $\mathrm{MC}\left(M C_{2}\right)$ of the timber, the target $\mathrm{MC}$ would be achieved. However, if $M C_{1}$ was higher than $M C_{2}$, the timber would appear to be over-dried. In addition, kerfs have not been found to have any influence on the drying speed of the timbers. About 10 to 20 cycles of microwave heating was usually needed to reach the target MC of about $30 \%$. Therefore, it was possible to dry the timbers to the desired MC within 10 hours, as a cycle took about 30 minutes. Considering the relatively long duration of $\mathrm{KD}$ ( $>2$ days), the drying time of timbers by MD was significantly short.

\subsection{Surface checks}

The surface check of the dried $12 \mathrm{~cm}$-diam.timber is shown in Fig.8-a. After MD, the timbers without kerf showed no surface check when their final MCs were lower than $10 \%$. However, surface checks were observed when the final MCs were about $10 \%$ or more. In the case of $\mathrm{KD}$, obvious surface checks were detected on most of the timbers free of kerf without any correlation to the final $\mathrm{MC}$, which ranged from $30 \%$ to $90 \%$. No surface check was ob-

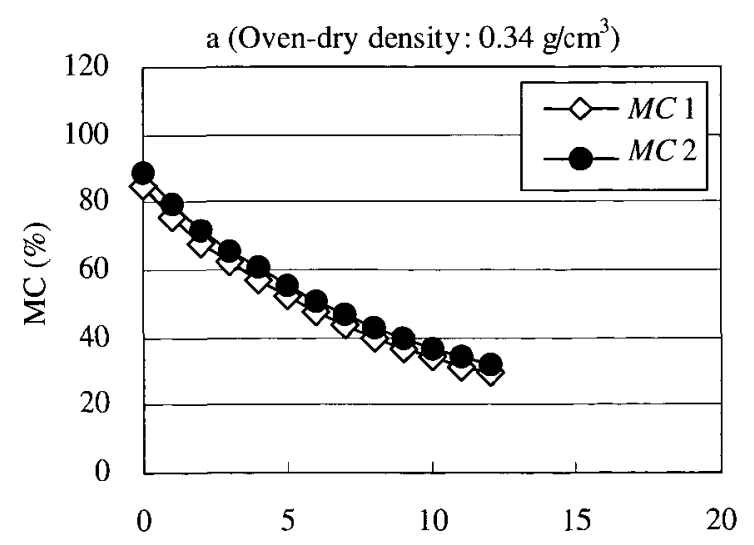

Frequency of microwave irradiation (cycle)

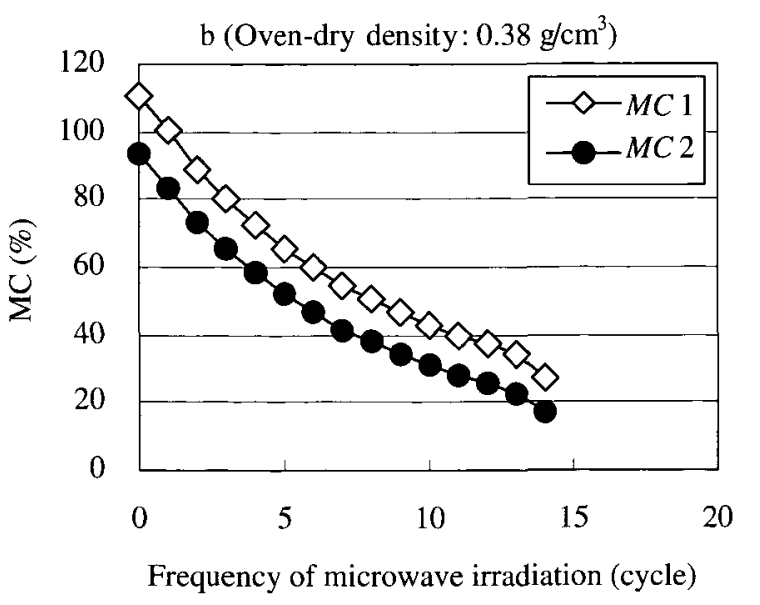

Frequency of microwave irradiation (cycle)

Fig.7 Changes of MC during MD (12 cm-diam.timbers, target MC 30\%, without kerf)

Note: $M C_{1}$-presumptive $M C, M C_{2}$-actual $M C$

図 7 スギ円柱材のマイクロ波加熱処理における含水率経過（直径 $12 \mathrm{~cm}$, 目標含水率 $30 \%$, 背割り無し） 注：MC -推定された含水率, $M C_{2}$-実際の含水率 


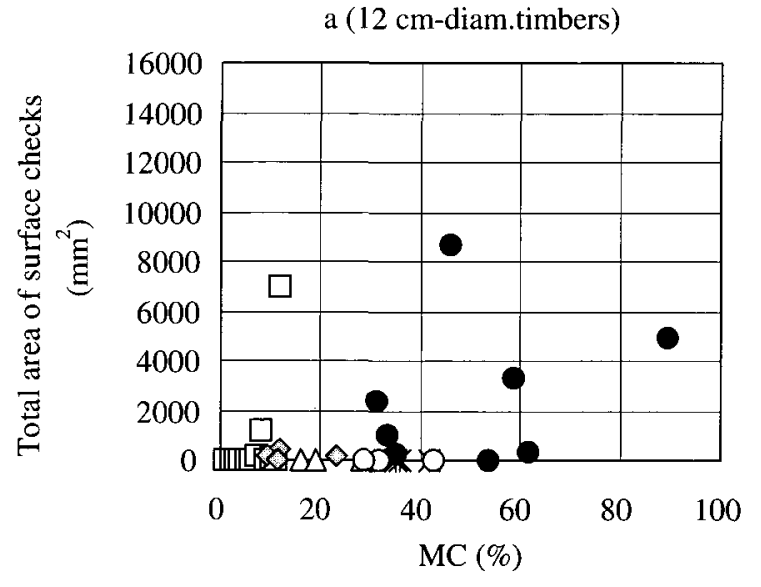

$\square \mathrm{MD}$, without kerf $\diamond \mathrm{MD}$, with a kerf $* \mathrm{KD}$, with a kerf b (9 cm-diam.timbers)

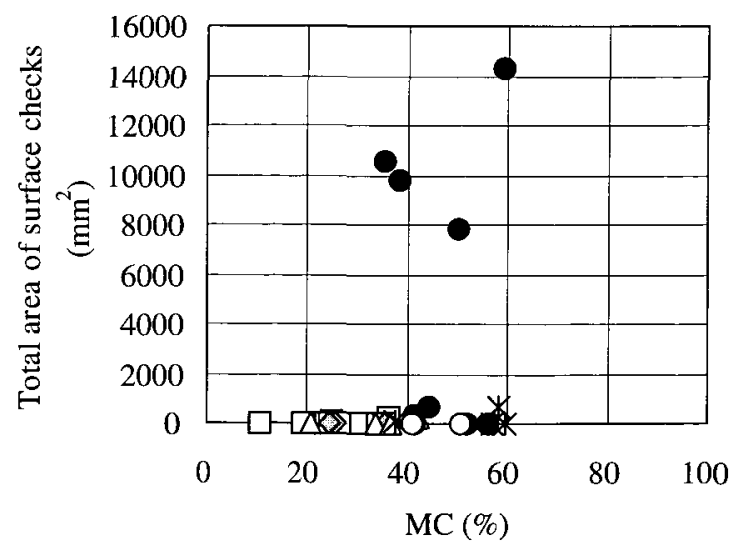

$\triangle \mathrm{MD}$, with 4 kerfs

$\mathrm{O} \mathrm{KD}$, with 4 kerfs

Fig. 8 Relationship between surface checks and finish MCs in each drying condition 図 8 各乾燥条件における表面割れと仕上がり含水率の関係
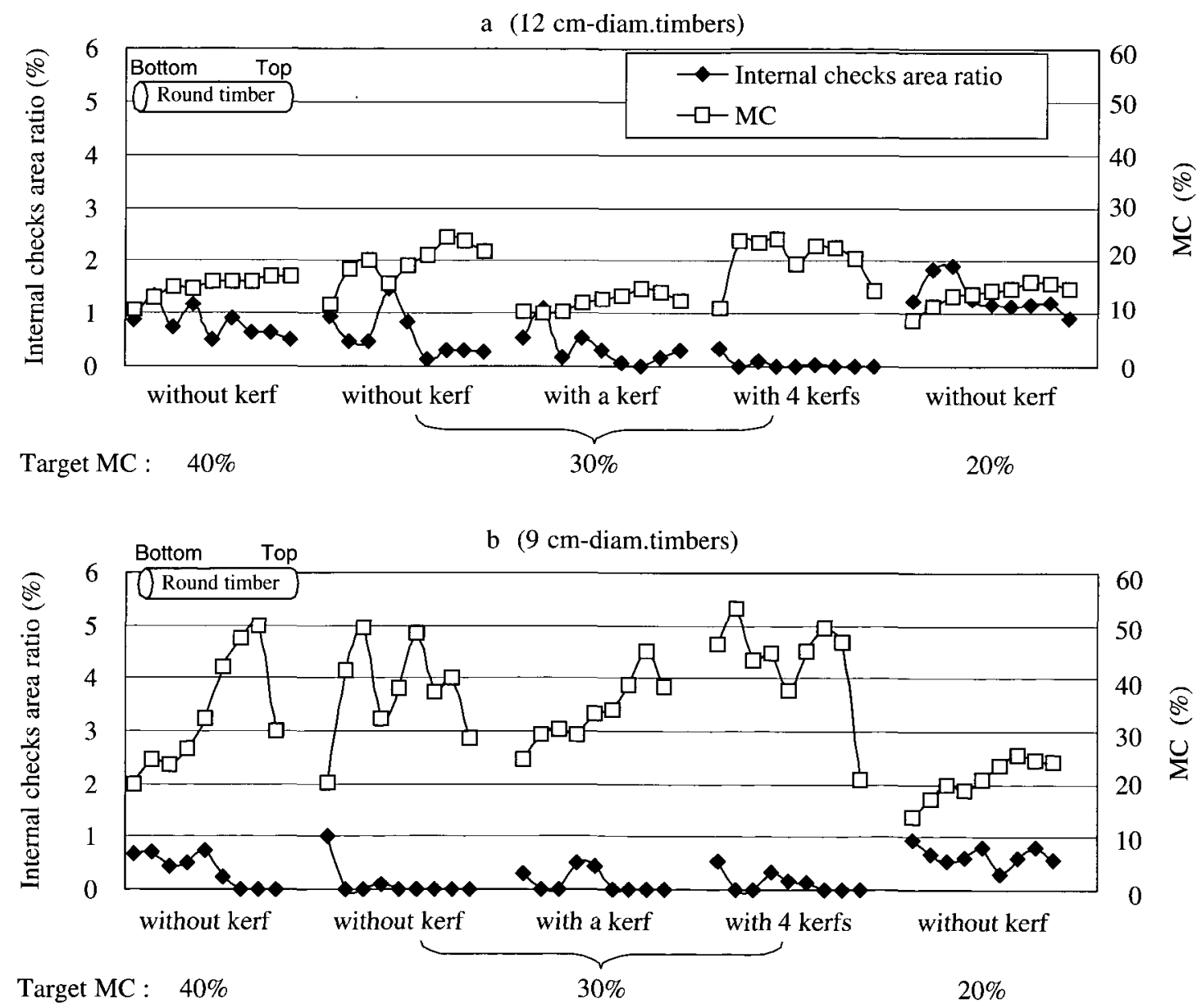

Fig.9 Distribution of internal checks and MC along the longitudinal direction of the timber dried by MD Note : Bottom-Bottom end of the timber, Top-Top end of the timber

図 9 マイクロ波乾燥における内部割れと含水率の材長方向分布

注：Bottom-元口，Top-末口

served on the $9 \mathrm{~cm}$-diam.timbers without kerf after MD to an MC range of $10-40 \%$ (Fig.8-b). Half of them generated surface checks upon $\mathrm{KD}$ to an $\mathrm{MC}$ range of $35-60 \%$. In the timbers with 1 and 4 kerfs, 
no surface check was observed due to either MD or KD.

Due to the fact that MD caused the inner layer to dry quickly, a compression stress on the surface layer is likely to result, thereby avoiding the formation of surface checks.

\subsection{Internal checks}

The internal checks and MC distribution along the longitudinal direction from the bottom end to the top end of the $12 \mathrm{~cm}$-diam.timber dried by MD are shown in Fig.9-a. When the final MC of the timbers was around the range of $9-25 \%$, internal checks occurred frequently in most of the timbers. Since the bottom area showed a lower MC than the top area, more internal checks were formed in the bottom area. In timbers with a target $\mathrm{MC}$ of $20 \%$, the internal checks occurred more frequently. At a target $\mathrm{MC}$ of $30 \%$, the formation of internal checks declined according to the number of kerfs.

Compared to the $12 \mathrm{~cm}$-diam.timbers, the $9 \mathrm{~cm}$ diam.timbers showed fewer internal checks because their final MC was higher than those of the former
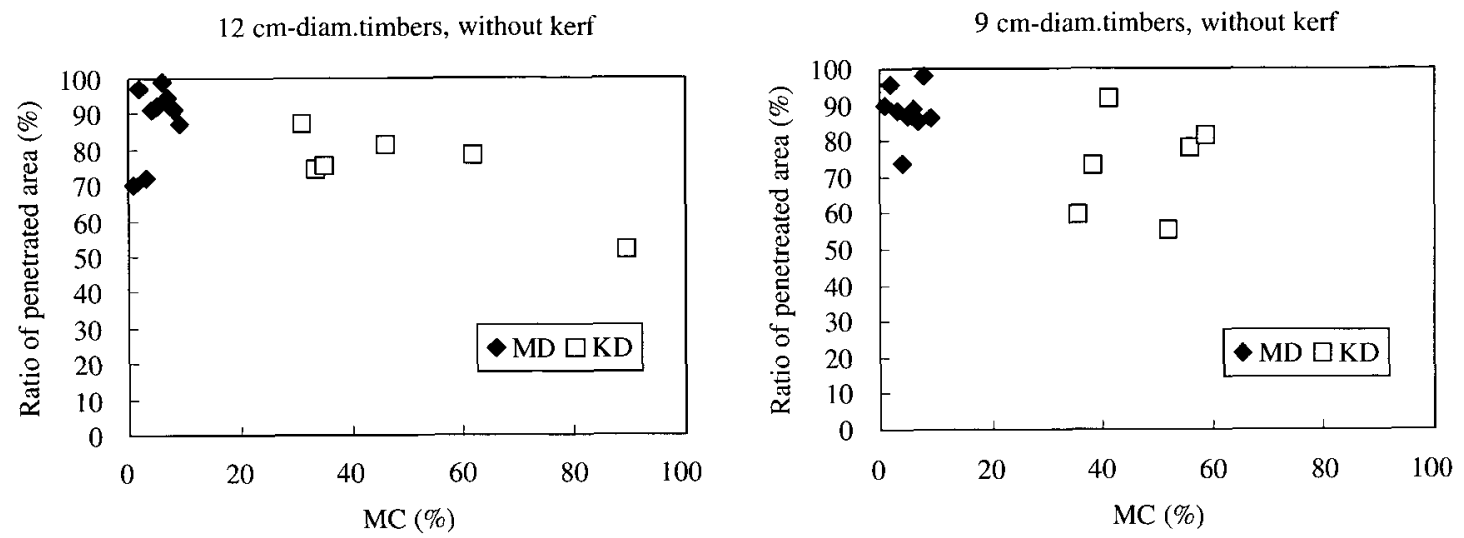

Fig.10 Effect of MD and KD on the penetrated area of the preservative Average amount of impregnated preservative :

$12 \mathrm{~cm}$-diam.timbers, without kerf, MD : $517.3 \mathrm{~kg} / \mathrm{m}^{3}, \mathrm{KD}: 403.5 \mathrm{~kg} / \mathrm{m}^{3}$

$9 \mathrm{~cm}$-diam.timbers, without kerf, MD : $452.7 \mathrm{~kg} / \mathrm{m}^{3}, \mathrm{KD}: 378.3 \mathrm{~kg} / \mathrm{m}^{3}$

図10 浸潤面積に与えるマイクロ波と蒸気乾燥の影響

平均注入量：直径 $12 \mathrm{~cm}$, 背割り無材, $M D: 517.3 \mathrm{~kg} / \mathrm{m}^{3}, \mathrm{KD}: 403.5 \mathrm{~kg} / \mathrm{m}^{3}$

直径 $9 \mathrm{~cm}$ ，背割り無材，MD: $452.7 \mathrm{~kg} / \mathrm{m}^{3}, \mathrm{KD}: 378.3 \mathrm{~kg} / \mathrm{m}^{3}$
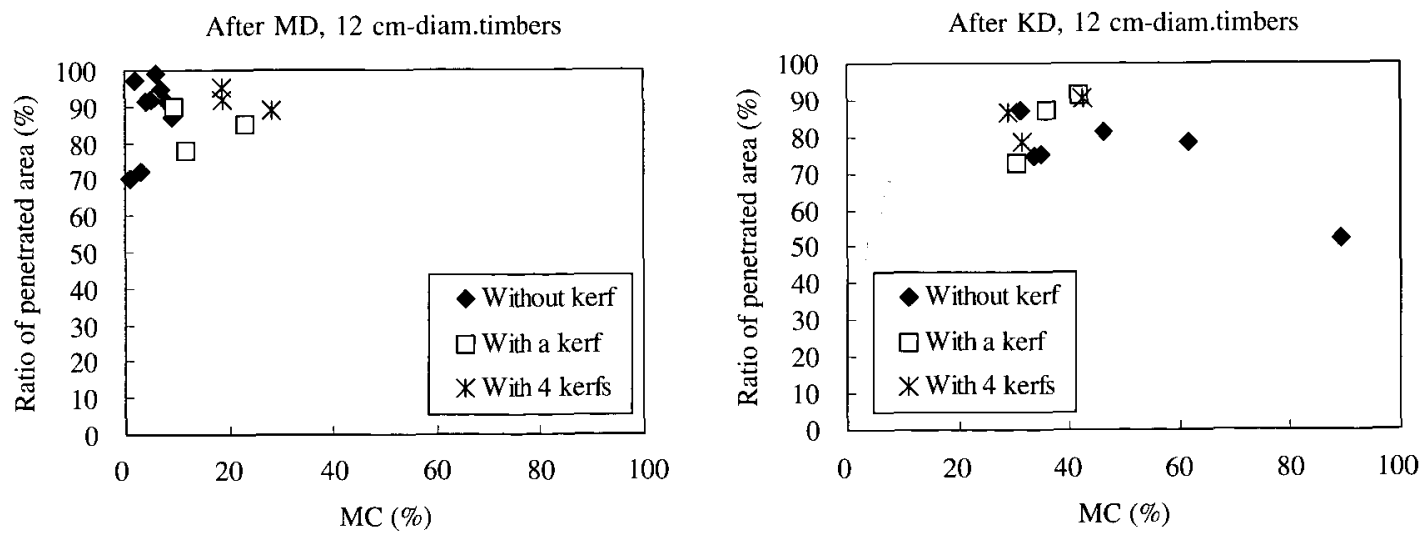

Fig.11 Effect of the kerfs on the penetrated area of the preservative Average amount of impregnated preservative :

MD-0, 1 and 4 kerfs : $517.3 \mathrm{~kg} / \mathrm{m}^{3}, 446.9 \mathrm{~kg} / \mathrm{m}^{3}, 479.2 \mathrm{~kg} / \mathrm{m}^{3}$

$\mathrm{KD}-0,1$ and 4 kerfs : $403.5 \mathrm{~kg} / \mathrm{m}^{3}, 412.6 \mathrm{~kg} / \mathrm{m}^{3}, 435.1 \mathrm{~kg} / \mathrm{m}^{3}$

図11 浸潤面積に与える背割りの影響

平均注入量：MD- $0 ， 1 ， 4$ 本背割り材 : $517.3 \mathrm{~kg} / \mathrm{m}^{3}, 446.9 \mathrm{~kg} / \mathrm{m}^{3}, 479.2 \mathrm{~kg} / \mathrm{m}^{3}$

KD-0，1，4 本背割り材: $403.5 \mathrm{~kg} / \mathrm{m}^{3}, 412.6 \mathrm{~kg} / \mathrm{m}^{3}, 435.1 \mathrm{~kg} / \mathrm{m}^{3}$ 
(Fig.9-b). The internal checks were distributed in the longitudinal direction according to $\mathrm{MC}$ distribution on both the timbers. It means that MC could influence the formation of internal checks. The above results implied that it would be possible to improve the preservative permeability into the inner layer with internal checks through controlling the final MC by MD.

\subsection{Preservative permeability}

For the timbers without kerf dried by MD and $\mathrm{KD}$, the relationship between the preservative penetration area of the cross-section and MC of the timber is shown in Fig.10. Compared to timbers dried by $\mathrm{KD}$, those dried by $\mathrm{MD}$ could be dried more quickly, with a lower MC, and therefore could be well impregnated with the preservative. Similar results have been observed in the $9 \mathrm{~cm}$-diam.timbers.

The effect of kerfs on the ratio of area penetrated with the preservative for each drying method is shown in Fig.11. In both drying methods, obvious preservative permeability was found around the kerfs (Fig.12). However, there was no significant difference in the penetrated area of the preservative among timbers with 0,1 and 4 kerfs.
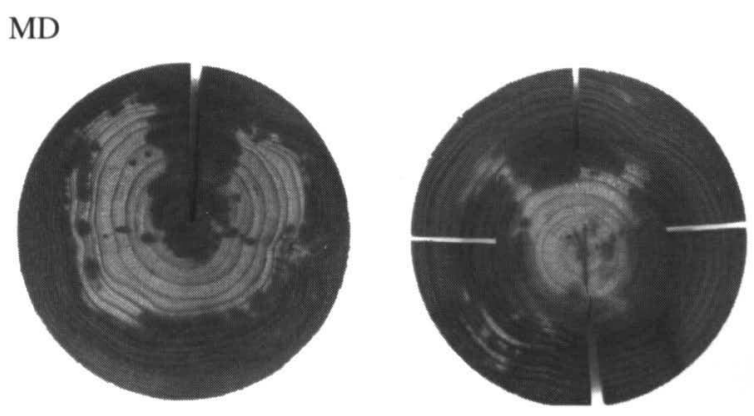

KD
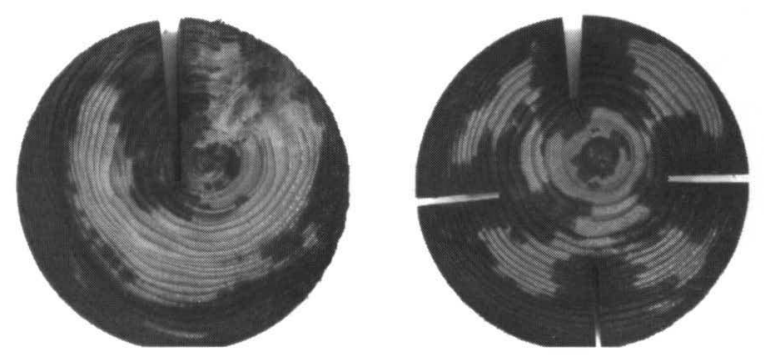

Fig.12 Preservative penetration at the kerfs 図12 背割り部分の防腐剂浸潤
Acknowledgments

This study received financial support from Forestry Agency, Ministry of Agriculture Forestry and Fisheries of Japan.

\section{REFERENCES}

1) Kobayashi, Y., Iida, I., Imamura, Y. and Watanabe, U. : Drying and anatomical characteristics of sugi wood attacked by bacteria during pond storage, Journal of Wood Science, 44 (6), 432-437 (1998).

2) Hayashi, K., Park, J.S. and Nakamura, K. : Trial approach to the estimation of size distribution of free water paths in the undried heartwood of softwoods by a centrifugal method, Journal of Wood Science, 45 (1), 1-9 (1999).

3) Matsunaga, M., Matsunaga, H., Kataoka, Y. and Matsui, H. : Improved water permeability of sugi heartwood by pretreatment with supercritical carbon dioxide, Journal of Wood Science, 51 (2), 195-197 (2005).

4) Adachi, K., Inoue, M. and Kawai, S. : Liquid impregnation of green wood using a roller-pressing method, Mokuzai Gakkaishi, 51 (3), 159-165 (2005).

5) Piao, J., Fujimoto, N., Oohashi, K., Tanikawa, M.Kitada, M., Sonobe, H. and Ueda, Y. : Drying properties of sugi round timber with microwave heating, J.Fac.Agr., Kyushu Univ., 51 (2), 345-349 (2006).

6) Fujimoto, N., Morita, Y., Oouchi, T., Lin, H.C., Oohashi, K. and Kondo, K. : Drying of sugi logs with microwave heating, Journal of the Society of Materials Science Japan, 54 (4), 371-376 (2005).

(2006. 10.31受付)

(2007. 4 .10受理) 